\title{
Diagnosing low back pain in an evidence-based way: How accurate are we?
}

\author{
ISSN: 2455-5487 DOI: https://dx.doi.org/10.17352/jnppr \\ Received: 05 October, 2020 \\ Accepted: 21 October, 2020 \\ Published: 22 October, 2020 \\ *Corresponding author: Rilind Shala, Department \\ of Physiotherapy, University of Prishtina, Prishtine, \\ Kosova, Tel: +38344/361/176; \\ E-mail: rilindshala@hotmail.com \\ Keywords: Low back pain; Efficacy; Diagnosis; \\ Evidence-based \\ https://www.peertechz.com
}

Rilind Shala*

Department of Physiotherapy, University of Prishtina, Prishtine, Kosova

Back pain is the leading cause of disability globally with 818,000 disability-adjusted life 51 years estimated to be lost annually due to work-related Low Back Pain (LBP) [1].

Low back pain is the fifth leading reason patients seek medical attention in the United States [2]. Despite this high prevalence, the etiology and nature of chronic low back pain (CLBP) are not yet fully understood.

Most people - and most health care professionals believe that back pain is usually caused mainly by structural problems, either injury or degeneration of the spine. But is this the case? Are problems with low back pain always structural, or is there any other component involved here?

Research right now tells us that the opposite might be more true. Moseley reported that "The evidence that tissue pathology does not explain chronic pain is overwhelming (e.g., in back pain, neck pain, and osteoarthritis)" [3]. The correlation between structural problems and pain is often not how we clinicians think it is, many structural problems are "over-diagnosed" without having a correlation with pain, or are often labeled as the cause of pain."How can you say that? I always have patients with spondylolisthesis and spinal stenosis who have disabling back pain." Well, maybe not. In 2006, Haig, et al. published a truly surprising paper where they reported that spinal stenosis often does not hurt. In this study, about 150 people were assessed for back pain either with MRI alone or just with physical assessment. MRI can certainly detect narrowing of the spinal canal, but with MRI alone, the clinicians could not identify which patients were with pain, because many of the people who had stenosis did not have pain [4].

NEJM has also published a case of a traumatic cervical spine dislocation, but surprisingly it was mostly asymptomatic. He had fallen from standing height but did not report subsequent cervical pain, weakness, or paresthesia [5]. Many more papers reported these findings over and over again. One of the best examples is the study of Brinjikji, et al. where they found out that signs of spinal degeneration are present in very high percentages of healthy people with no symptoms at all [6].

These studies are getting repetitive, where these results are being reported over and over again, but have we learned the lesson as clinicians? If I had to guess, I would say certainly not, but luckily there are studies which can clear the doubts. In 2019, Zadro, et al. published a systematic review with the title "Do physical therapists follow evidence-based guidelines when managing musculoskeletal conditions?". The results? Shocking.

The median percentage of physical therapists who chose treatments with no recommendation was $81 \%$ [7]. If we want to be more optimistic, we can say that this will get better over time, as the evidence is overwhelming right now, but is this the case, again? In 2020, the same author, Zadro, et al. published another paper titled "Has physical therapists'management of musculoskeletal conditions improved over time? What are the results this time? Well, not promising. "Physical therapists' use of recommended care has not changed since the 1990s yet the use of treatments of unknown value appears to be increasing.", as reported by the authors. [8]. Not optimism here at all. Why is this happening? Isn't it 2020, and we have a large, large database of information right now? Musculoskeletal medicine was and is still a mess right now. Many over-valued and overrated treatments are being promoted, attracting clinicians and young graduates. Quick fixes and gimmicks are being promoted more than ever while having small or no evidence at all to support them. The need for new clinical innovation, getting an edge over the competition, the challenge of keeping up to date with evidence, increased exposure to treatments of 
unknown value, belief that evidence is not relevant to practice, and "this is how I have done it always" are potential reasons for this trend in musculoskeletal medicine.

\section{How can we clinicians improve and be as evidence- based as possible?}

1. Increasing access to information for clinicians

2. Publishing as many "clinically oriented" papers as possible

3. Holding sessions and conferences especially for improving clinical practice

4. Educating patients that a "quick fix" is often, not possible, regardless of the clinician

5. Focusing more to the patient as a whole, in a biopsychosocial way, and not in a structural, biomedical approach

\section{References}

1. Buchbinder R, Blyth FM, March LM, Brooks P, Woolf AD, et al. (2013) Placing the global burden of low back pain in context. Best Pract Res Clin Rheumatol 27: 575-589. Link: https://bit.ly/31tQmfB
2. Hart LG, Deyo RA, Cherkin DC (1995) Physician office visits for low back pain Frequency, clinical evaluation, and treatment patterns from a U.S. national survey. Spine 20: 11-19. Link: https://bit.ly/2Hmvf82

3. Moseley GL (2012) Teaching people about pain: why do we keep beating around the bush? Pain Manage 2: 1-3. Link: https://bit.ly/37sbPJI

4. Haig AJ, Tong HC, Yamakawa KS, Quint DJ, Hoff JT, et al. (2006) Spinal stenosis, back pain, or no symptoms at all? A masked study comparing radiologic and electrodiagnostic diagnoses to the clinical impression. Arch Phys Med Rehabil 87: 897-903. Link: https://bit.ly/35kPKKm

5. Akhaddar A, Boucetta M (2010) Dislocation of the Cervical Spine. N Engl J Med 362: 1920-1920. Link: https://bit.ly/34gEnUH

6. Brinjikji W, Luetmer PH, Comstock B, Bresnahan BW, Chen LE, et al. (2015) Systematic Literature Review of Imaging Features of Spinal Degeneration in Asymptomatic Populations. AJNR Am J Neuroradiol 36: 811-816. Link: https://bit.ly/3jjsIZn

7. Zadro J, O'Keeffe M, Maher C (2019) Do physical therapists follow evidencebased guidelines when managing musculoskeletal conditions? Systematic review. BMJ Open 9: e032329. Link: https://bit.ly/34gEqzR

8. Zadro JR, Ferreira G (2020) Has physical therapists' management of musculoskeletal conditions improved over time? Brazilian Journal of Physical Therapy S1413355519310627. Link: https://bit.ly/34i4E4E
Discover a bigger Impact and Visibility of your article publication with

Peertechz Publications

\section{Highlights}

* Signatory publisher of ORCID

* Signatory Publisher of DORA (San Francisco Declaration on Research Assessment)

* Articles archived in worlds' renowned service providers such as Portico, CNKI, AGRIS, TDNet, Base (Bielefeld University Library), CrossRef, Scilit, J-Gate etc.

* Journals indexed in ICMJE, SHERPA/ROMEO, Google Scholar etc.

* OAI-PMH (Open Archives Initiative Protocol for Metadata Harvesting)

- Dedicated Editorial Board for every journa

* Accurate and rapid peer-review process

* Increased citations of published articles through promotions

* Reduced timeline for article publication

Submit your articles and experience a new surge in publication services (https://www.peertechz.com/submission).

Peertechz journals wishes everlasting success in your every endeavours.

Copyright: (c) 2020 Shala R. This is an open-access article distributed under the terms of the Creative Commons Attribution License, which permits unrestricted use distribution, and reproduction in any medium, provided the original author and source are credited.

Citation: Shala R (2020) Diagnosing low back pain in an evidence-based way: How accurate are we? J Nov Physiother Phys Rehabil 7(2): 060-061. 